\title{
PERSONALIDADE E PAPÉIS SOCIAIS DO XAMÃ ENTRE OS CARAÍBAS NEGROS
}

\author{
RUY COELHO \\ (Universidade de São Paulo)
}

Para compreender a dinâmica da personalidade e dos papéis sociais tal como se observa no xamã caraíba negro, faz-se necessário, como é óbvio, conhecer primeiramente os traços essenciais da cultura do grupo, a qual resultou de processos aculturativos que se estendem por três séculos. Os Garífuna, que se tornaram famosos sob o nome de caraíbas negros, constituem hoje em dia uma população de mais de sessenta mil indivíduos, formando como que um rosário de aldeias e vilas ao longo do litoral Centro-americano do Mar dos Caraíbas. Sua existência como grupo étnico independente começou em St. Vincent, Antilhas Britânicas, onde escravos, fugidos de navios negreiros ou de plantações das ilhas vizinhas, se aliaram aos índios caraíbas. A miscigenação entre os dois grupos foi pouco intensa, mas a absorção de elementos culturais aborígenes pelos africanos se realizou com rapidez e facilidade.

Uma vez integrados em uma sociedade coêsa, os Garífuna viveram quase permanentemente em estado de guerra, a princípio contra os seus ex-senhores, os caraíbas "vermelhos", os quais foram dizimados e expulsos das ilhas; depois, contra tôdas as potências coloniais que agiam nas Antilhas. Suas revoltas sucessivas contra a Coroa Inglêsa, que obtivera jurisdição sôbre St. Vincent, culminou no grande levante de 1797. Tendo sofrido derrota definitiva, foram deportados em massa para a ilha de Roatan, Honduras, de onde se dispersaram pela região que ocupam no presente.

Os caraíbas negros elaboraram uma cultura homogênea, cujas principais instituições se articulam segundo dois princípios fundamentais: a necessidade de operar mudanças de modo lento e gradativo, e a reciprocidade de direitos e obrigações. O primeiro dêles faz-se sentir mesmo nas concepções relativas ao ciclo de vida. Supõe-se que ao recém-nascido falte um dos elementos da alma (o "duplo"), que só lhe vem após o sétimo dia de vida. O casamento é o último passo na estabilização de uma união sexual. Da mesma forma, a morte é concebida como transição gradativa, sendo a fase inicial do processo de divinização dos antepassados. 
O princípio de reciprocidade enforma a estrutura e a organização social do grupo. À medida que o indivíduo avança em anos e se aproxima mais do mundo dos espíritos, adquire maior experiência e sabedoria. São os velhos, pois, que detêm a maior soma de autoridade, porque se acredita que contribuam maiormente para o bem-estar geral. Os padrões ideais das relações paritárias dão realce à necessidade da colaboração harmoniosa e independente entre parceiros. Ambos os esposos provêem às necessidades da família; compete ao marido fornecer o peixe e a carne, e à mulher, os produtos agrícolas .

As regras que se observam na vida quotidiana entre os mortais são de tipo idêntico às que governam as relações entre os sêres sobrenaturais. O universo é concebido como um imenso campo de batalha onde se defrontam contendores vários, que podem, eventualmente, tornar-se protetores de alguém que lhes solicite ajuda. Apesar dos Garífuna serem nominalmente católicos, a separação dos espíritos em bons e maus é bastante indistinta na sua mente. Santos e demônios, animais fantásticos da floresta, espíritos das águas e dos cerrados são todos suscetíveis de interessar-se pela sorte do indivíduo que saiba propiciá-los. Mas os protetores naturais, com que se pode contar, são os membros desencarnados da própria família, cujo poder aumenta com o desenrolar dos ritos que promovem a sua divinização. Dentre êstes, os mais importantes são o "banho das almas", o "banquete das almas" e a "dança das almas", a que se associam as missas por intenção dos mortos. Do pagamento das promessas aos santos, da observância das estipulações contidas nos pactos com os espíritos, e da realização das cerimônias para os antepassados dependem a prosperidade terrena. A falha no cumprimento dessas obrigações acarreta o desinterêsse, ou, mais comumente, a ira dos poderes sobrenaturais .

E' lícito dizer-se, pois, que a vida do caraíba negro é dominada pela preocupação com as fôrças supraterrenas, isto é, pela religião e pela feitiçaria, entre as quais é difícil estabelecer limites precisos. Não se pode, no entanto, aplicar ao caso o estereótipo do primitivo esmagado pelo terror do sobrenatural, aliás, bastante desacreditado pelos estudos modernos. Se a sua trajetória na terra parece ao Garífuna içada de perigos, apesar disso êle crê possuir os meios para debelá-los. O espiritual, que penetra todos os escaninhos do quotidiano, não se apresenta como distante e inescrutável. Ao ocidental, em cuja atitude religiosa o respeito sempre se mescla ao temor, pode parecer estranho que o fiel graceje com o deus. Num dos ritos da "dança das almas", um grupo de rapazes vestidos de mulher, entre trejeitos e frases obscenas, faz a paródia dos momentos mais solenes da cerimônia. Comentando êsse passo, dizia-me o velho xamã Faustino Fernandez: "E então o neto não pode brincar com o avô?" A frase é sumamente reveladora e dispensa uma longa explana- 
ção sôbre as reações básicas do caraíba negro frente ao espiritual, em que o sentimento de veneração se liga à familiaridade.

Mas nem sempre os espíritos estão para brincadeiras. A passagem de um membro da família para o plano supraterreno tem por efeito, muitas vêzes, torná-lo caprichoso, irritadiço e inconseqüente, do mesmo modo que a criança que inicia a vida em nosso mundo. E as exigências que fazem são excessivas, descabidas, vazadas, não raro, em têrmos obscuros. Os santos da Igreja Católica, na reinterpretação da cultura, não estão isentos das paixões humanas; alguns são tidos por coléricos, como S. Francisco de Cordón, em cujo dia festivo há sempre uma tempestade. Os espíritos "não-cristãos", por sua própria natureza misteriosa e diversa da humanidade, são os mais imprevisíveis, e os que mais dão motivo de apreensão. O homem prudente é aquêle que manda rezar missas e celebrar as cerimônias nativas para os ancestrais, nas datas prescritas, que acende velas aos santos e procura não ofender os sêres sobrenaturais do êrmo.

Se a doença, os acidentes de pesca, a perseguição da polícia ou outra calamidade qualquer se abate sôbre a família, é necessário descobrir a causa. Para tanto, consulta-se um perito; será, conforme o caso, o "empírico", que conhece as virtudes das ervas, o "curandero", sabedor de orações fortes e fórmulas mágicas, o "brujo", capaz de defender o cliente contra a feitiçaria, ou o "búiei" (xamã). Na prática, não se encontra alguém que se enquadre numa categoria apenas. Todo caraíba tem suas rezas milagrosas e confia nos efeitos curativos de certas plantas; a acreditar-se no diz-que-diz-que da aldeia, não há quem não pratique ocultamente alguma forma de feitiço. O profissional, naturalmente, possui maior eficiência em tôdas essas artes, mas só quando dirigir os ritos e fôr capaz de se pôr em comunicação com os espíritos será chamado "búiei". A êle se recorre quando falham as explicações comuns para as desgraças e para as doenças que resistam mesmo ao tratamento do médico branco.

O xamã é especialmente chamado a prestar serviços nas épocas de penúria, causada por catástrofes naturais ou pelas devastações que acompanham as crises da ordem pública. Cria-se, assim, um círculo vicioso: exatamente quando as circunstâncias impõem que se realizem cerimônias dispendiosas é que faltam os recursos financeiros para tal. Nessas ocasiões, coloca-se para muitas famílias o dilema de viverem na ansiedade, em virtude das obrigações não cumpridas, ou contraírem pesadas dívidas para atender aos gastos necessários. "Mais il est avec le ciel des acommodements". O "búiei" experiente conduz com habilidade as negociações entre os vivos e os mortos, de forma a obter compromissos razoáveis. Quando as discussões se tornam mais ásperas, faz-se apêlo ao sentimento de família dos "gubida" (antepassados divinizados), que, ao mostrarem-se demasiado severos para com os seus descendentes, correm o risco de vê-los extinguir-se, e não ter mais quem lhes renda culto. 
Além do adiamento dos ritos, os espíritos se mostram irritados com uma transgressão de qualquer ordem. Cumpre esclarecer, neste particular, que a noção cristã do pecado, isto é, da quebra de um preceito automàticamente associada ao sentimento de culpa, é estranha à mentalidade caraíba. Certamente, existe um código de ética na cultura, mas que não se expressa num sistema explícito e minucioso. As regras que o constituem são de âmbito muito geral, e a aplicação a cada caso particular varia de acôrdo com fatôres diversos. Nas dificuldades da existência, quando certas irregularidades se apresentam como inelutáveis, os espíritos fazem vista grossa. Se um chefe de família se distinguiu em vida pela austeridade moral, é provável (mas não fatal) que não mude depois da morte. Seus descendentes diretos têm que se pautar por normas mais rígidas do que as seguidas pelos sobrinhos, filhos de um irmão mais indulgente. Em suma, a ética dos Garífuna se assemelha ao sistema jurídico anglo-saxão, em que a base é a jurisprudência e o costume local. Talvez o único preceito absoluto seja o de não romper a harmonia do universo, pela infração do princípio de reciprocidade.

Segue-se disso que, na grande maioria dos casos, a culpa é exteriorizada: łrata-se de saber o que desagradou o "gubida" e qual a reparação exigida. Pode ser que a suscetibilidade do espírito tenha sido ferida por l:m ato imper cadi, que não constitui pròpriamer e uma prevalicaçâo: por exemplo, a venda de uma propriedade que the era cara e que desejava continuasse na família. (Num exemplo especítico, que foi observado de perto, as despesas com as cerimônias, segundo urna versão que corria pela aldeia, teriam correspondido, até a aproximação de centavos, à soma apurada na transação. O que era dado como prova da onisciência dos "guibida").

Assim, pois, a religião não é, para o caraíba negro, o domínio do recôndito e do incognoscível por excelência. Sem dúvida, os pensadores do grupo se propõem os enigmas do universo em têrmos teológicos. Mas o homem comum sente necessidade de conhecer, em dados concretos e inequívocos, a vontade dos ancestrais, para guiar-se na vida prática. Da mesma forma, faz-se mister ter noções acêrca do modo de existência e das características dos diversos espíritos, para evitar perigos e formar alianças proveitosas. Todos os fatos fazem parte da mesma trama sobreratural. O pescador, que hesita em aventurar-se ao mar quando há prenúncios de temporal, busca a opinião do "búiei", movido pelas mesmas razóes que levam, em outras culturas, a consultar o serviço meteorológico. Em outras palavras, a religião é, para os caraíbas negros, o foco cultural .

Ao cunhar essa expressão, Herskovits quis com ela designar "a tendência de tôda cultura a manifestar maior complexidade em certos aspectos de preferência a outros", e definiu-a como sendo "a preocupaçäo dominante de um grupo" (...) "a área de atividades ou crenças em que existe consciência mais aguda da forma, em que se ouvem mais discussc̃es 
acêrca de valores, em que se verificam as diferenças mais marcadas de estrutura" ${ }^{1}$. E', pois, no foco cultural que surgem, em plena luz, os princípios que regem a integração, as inovações e o desenvolvimento de um sistema sócio-cultural. A utilização dêsse conceito permite pôr em relêvo a ação que o homem exerce sôbre as instituições, destacando as expressões culturais produzidas pelas fôrças criadoras da psique humana. Um estudo em que se escolhe essa via de exploração incide, necessàriamente, sôbre os processos que definem a transição do comportamento individual para a conduta social. A socialização, que desempenha parte importante na formação da personalidade, também prepara o indivíduo para ocupar o lugar que the compete na vida do grupo. No decurso de sua existência, êle tem acesso a diferentes status e deve aprender os papéis que lhes correspondem .

A discussão em tôrno dos diferentes significados do têrmo papel é dispensável; ùltimamente tem-se firmado a noção de que êsse conceito deve ter maior compreensão lógica do que na sua caracterização como aspecto dinâmico do status. A fórmula é correta, sob certo aspecto, para um grande número de casos, mas deixa de considerar um outro lado da questão, isto é, que o papel é uma configuração de normas e padrões que se tornam constituintes do modo de agir do membro do grupo, que lhe imprime o sêlo de sua personalidade. A analogia evocada pela acepção teatral da palavra pode levar a crer que o papel social é um conjunto de pautas para a ação que o indivíduo assume ou descarta, conforme the ditam as circunstâncias com que se defronta. Parece mais consentâneo com os fatos admitir que cada qual vive um papel de forma distinta, e que as atividades por êle coordenadas passam a fazer parte de um comportamento individualmente delimitado.

Imñ̃e.-s também à consideração que as diferentes sociedades se di unguem pela maior ou menor rigidez no circunscrever a latitude permissível no desempenho de papá: . Dentro da mesma sociedade há setores em que a tolerância é maior, em rue se deixa, portanto, liberdade mais ampla a certos indivíduos. No sistema súcin-cultural dos caraíbas negros, como o quadro sucinto que aqui se traçou permitıria sup on os papéis são definidos com tôda a nitidez. Do berço ao túmulo, há senucs pré-traçadas que conduzem mansamente a criatura humana do estágio irfantil ao da adolescência, e desta à maturidade, à velhice, à morte, e à entronização final, nos céus, como espírito protetor da família.

O observador que se ativesse ao plano superficial só poderia constatar, no entanto, que há uma grande diversificação nas atividades exercidas pelos Garífuna. Nos portos e aldeias de Guatemala, Honduras e Honduras Britânica, além de cultivarem a terra e se dedicarem à pesca, sâo caraíbas os melhores artesãos, tais como marceneiros, serralheiros, cán inteiros, mecânicos, encanadores e eletricistas. Nos navios, servem como má-heiros, pilotos, ou mesmo capitães; nos hotéis, como cozi- 
nheiros, "garçons" e "barmen". O número de professôres primários é relativamente elevado entre êles; em Honduras Britânica, segundo a declaração de um oficial da colônia, formam a espinha dorsal do sistema de ensino. A versatilidade nas ocupações e a proficiência que os membros do grupo atingem nelas constituem motivo de orgulho e são constantemente invocadas nas discussões com estranhos. Em tais ocasiões, procura-se exaltar as qualidades da "raça" (palavra de que os caraíbas negros usam a miúde), e não o brilho peculiar a tal ou qual indivíduo.

O dinheiro e o prestígio resultantes do êxito profissional constituem, naturalmente, fatôres que agem sôbre os mecanismos definidores do status, mas são, por assim dizer, periféricos. Os homens ricos, entre os Garífuna, não procuram destacar-se dos demais por um estilo de vida mais luxuoso e não esperam que lhes seja tributada maior consideração, a não ser que, como sucede em muitos casos, o aumento da fortuna se tenha acompanhado da acumulação de experiência e sabedoria que os anos trazem. A opinião dos estranhos ao grupo pouco vale para um caraíba negro; o que lhe importa é assegurar a posição que ocupa em sua própria sociedade. A feição religiosa que assumem os laços sociais contribui para perpetuar a estrutura. As cerimônias do culto dos mortos, cuja realização congrega periòdicamente todos os descendentes de um tronco comum, reavivam o conteúdo afetivo das relações familiares, fortalecendo assim a coesão social. E como os papéis se delimitam a partir de uma ordem que tem bases sobrenaturais, e os sistemas de ação que configuram são adaptáveis a cada caso singular, resulta disto que a cultura manifesta homogeneidade aliada a flexibilidade, o que foi, certamente, de imensa importância para sua manutenção.

As estruturas básicas do comportamento dos Garífuna se erigem de acôrdo com princípios que não são perceptíveis à primeira vista. Sob a aparente diversidade de funções, encontram-se as polarizações de atividades que têm significado real aos olhos dos indivíduos. Em todos os núcleos de população, quer os situados na colônia britânica, quer os que se localizam em Honduras, Guatemala, Nicarágua ou Panamá, os caraíbas negros vivem segundo o mesmo sistema de valores, que dá forma a uma organização social sempre idêntica a si mesma. A permanência cronológica vai de par com a uniformidade espacial.

Se as instituições fundamentais exibem uma tão grande unidade, os processos educativos que nelas se estribam não devem também variar. Segue-se que as personalidades que se moldam pelas mesmas matrizes culturais teriam que apresentar uma fisionomia sensivelmente comum. Yo curso do programa de pesquisas que êste trabalho relata em parte, colheram-se cêrca de sessenta protocolos dos testes de Rorschach, cuja análise ainda está em andamento. Os resultados parciais já obtidos confirmam a suposição que aqui se faz. Embora os protocolos não se repitam uns aos outros com monotonia, o compasso de variação não é extenso 
e há entre todos um inegável ar de parentesco. Dois, no entanto, se destacam nitidamente dos demais, e acontecem ser, em ambos os casos, protocolos de "búieis", que se transcrevem por extenso no apêndice a êste artigo .

Não se procedeu ainda ao levantamento de um psicograma coletivo dos testes de Rorschach colhidos entre os caraíbas negros. Mas há traços comuns que repontam com clareza, tais como a predominância de respostas globais $(W)$; o número de respostas $(R)$ baixo; uma incidência alta de respostas de forma pura $(F)$, em geral de bom nível; a presença de um número regular de respostas de perspectiva $(F K)$; uma percentagem relativamente importante de respostas de forma-textura $(F C)$; tendências a elevar o número de respostas de movimento humano $(M)$; redução considerável das respostas de côr ( $F C$ e $C$ ) e preferência pelas tonalidades acromáticas ( $F C^{\prime}$ e $C^{\prime}$ ). Numa caracterização sumária com vistas ao público leigo, interpretam-se êsses dados como se segue ${ }^{2}$.

$\mathrm{O} W \%$ elevado indica um feitio mental eminentemente teórico, preocupado antes com os grandes esquemas do que com os significados particulares, o que é congruente com o $R \%$ baixo; torna-se evidentemente dificil multiplicar as respostas quando se usam as manchas de cada cartão como uma "Gestalt" total. Os caraíbas negros não têm, portanto, ambição de quantidade, mas sim de qualidade, o que se evidencia também na excelência das respostas de forma $(F+)$. O F\% comprova a vigilância consciente exercida sôbre o próprio comportamento, bem como a aderência ao real. O significado das respostas de claro-escuro e sombreado tem sido objeto das maiores discussões entre técnicos do Rorschach. Para o caso presente, foi adotada a posição de Klopfer, que parece dar melhor conta dos fatos. Assim, as respostas que implicam visão tri-dimensional $(F K)$ são tidas por indicadoras de uma autoconsciência desenvolvida, tal como surge no indivíduo que se interroga constantemente sôbre si mesmo. Quanto ao $F c$, é geralmente aceito que a sensibilidade às qualidades táteis das manchas de tinta deva ser relacionada com o tato, na acepção figurada da palavra. O significado da predominância do $M$ sôbre o $C$ não padece dúvida, e se relaciona com o que se chama vulgarmente "introversão", conceito que passou por várias retificações desde cue foi lançado por Jung. Rorschach propos o uso de introversivo, em lugar de introvertido, que se adapta melhor à descrição da mentalidade caraíba, a qual se distingue pela riqueza da vida interior, sem que, no entanto, estejam bloqueadas as vias de acesso ao mundo externo. A pequena proporção das respostas de côr e a presença de $C$ ' configuram, na terminologia de Klopfer, a reação "burnt child", cujo equivalente em porıuguês seria "gato escaldado". Encontra-se geralmente nas pessoas que passaram por experiências traumáticas e, como conseqüência, perderam a capacidade de reagir espontâneamente aos estímulos exteriores. 
A análise do sistema sócio-cultural dos Garífuna em têrmos de personalidade básica está reservada para um trabalho futuro. Mas o arrolamento sumário dos dados do Rorschach aqui tentado já permite vislumbrar alguns traços gerais. O fato de a religião ser o foco cultural traduzse, no plano psicológico, pelo gôsto por esquemas abstratos $(W \%)$, e pelo desenvolvimento da vida interior $(M)$. O contrôle estrito exercido sôbre a própria conduta, a prudência nas relações interpessoais, a cautela no modo de estabelecer contactos com o mundo, refletem, inequivocamente, os resultados da experiência coletiva do grupo no decurso de sua história .

Visto contra êsse pano de fundo, o teste do "búiei" Siti Garcia se apresenta como um quadro em que as tendências gerais do grupo são acentuadas. As reações às tonalidades acromáticas e aos estímulos de côr, que se encontram em pequeno número em outros protocolos, estão ausentes. No lado esquerdo do psicograma de Klopfer consignam-se tão sòmente duas respostas $F C$; juntando-se a êsse dado o número de $M$ (6), conclui-se que o mundo exterior tem, em si mesmo, pouco interêsse para Siti, que vive imerso em suas próprias lucubrações. A percentagem de $W(58,33 \%)$ é inusitadamente elevada, mesmo em se tratando de um grupo no qual, como se viu, êste é o tipo predileto de abordagem intelectual. A baixa coluna de forma, na proporção $F$ total $=25 \%$, constitui

c. traço que mais se afasta do modêlo comum, e indica, na personalidade analisada, um domínio consciente mais frouxo e menor capacidade de referir sua experiência a padrões impessoais.

O conteúdo do teste é também revelador de algumas preocupações características dos caraíbas, quais sejam as que se relacionam com perigos marítimos e com a hostilidade ou proteção dos espíritos, aliás, intimamente ligadas. E' natural que tais preocupações sejam mais marcadas num "búiei".

O protocolo de Timotéa Zuñiga é, quanto a certos aspectos particulares, o mais atípico dentre os da amostra colhida. Há uma riqueza de determinantes maior do que a usual, embora a sua distribuição resulte numa configuração semelhante à dos demais, sobretudo no que diz respeito à soma $C$ (1) e a $C^{\prime}$, como também a $F c$. Isto é, evidenciam desconfiança em relação ao universo e exercício constante do tato. O número absoluto dos $M$ é o mesmo de Siti Garcia (6), mas proporcionalmente sua importância se reduz, mostrando tendência introversiva bastante menor. Há entre os Garífuna, como ficou demonstrado, a tendência a uma coluna de forma alta, que em Timotéa aparece mais pronunciada $(66 \mathrm{~F} \%)$. Neste caso, tem-se um contrôle estrito sôbre a conduta, ' $m$ que a conformidade com o real visa a anular os componentes pessoais da experiência. Vai de par com esta uma característica que diverge radicalmente das reações dos caraíbas negros e que, salvo melhor juízo, não 
é encontrada freqüentemente: a locação predominante nos detalhes mínimos interiores e periféricos $(D d 53 \%)$. A propósito do relêvo dado aos $d d$, modo de abordagem predileto de Timotéa Zuñiga, escreve Klopfer que é "uma defesa contra a insegurança por meio da busca da certeza e do apêgo a áreas limitadas", um modo de manter o pulso firme sôbre o leme, de mêdo que o navio se desgarre para o desconhecido. A predileção pelos detalhes minúsculos significa também, como é óbvio, o meticuloso amor à precisão. Quanto ao número de respostas, é de longe o mais elevado do grupo.

$\mathrm{Na}$ maneira de agir quotidiana, difîcilmente se poderia imaginar duas pessoas mais diferentes do que Siti Garcia e Timotéa Zuñiga: O primeiro se distinguia pelo espírito boêmio, com suas concomitantes: descaso ao dinheiro, negligência no vestuário, e alcoolismo crônico. Siti vivia na casa mais retirada de Rio Negro, que literalmente caía aos pedaços, num isolamento quase total. Pertencendo a uma sociedade intensamente gregária, não tinha amigos, recebendo apenas as visitas espaçadas dos clientes. As excentricidades de sua conduta eram notórias, mas quando cruzava pelas ruas da aldeia com passo incerto, porrete alçado na mão à guisa de cetro, dialogando com interlocutores invisíveis, nenhuma criança lhe saía ao encalço, seja por indiferença gerada pelo costume, ou temor. Ia à pesca, segundo voz corrente, tão só nas horas mortas da noite, voltando sempre com pesadas cargas de peixe. Os lucros profissionais pagavam-lhe a conta do botequim, e assim provia a sua existência.

A alcunha por que era conhecida Timotéa Zuñiga, Tetéa, não preparava o espírito para o encontro com um mulher de sessenta anos, de estatura imponente e corpulência majestosa. O rosto, emoldurado por panos engomados, daquela brancura que só as lavadeiras negras sabem dar, respirava complacência e autoridade. Viajava muito, e mal chegava a uma aldeia, à casa onde era hospedada com deferência acorriam logo as recém-casadas em dificuldades matrimoniais, as mães trazendo filhos pequenos, os doentes e aflitos de tôda espécie. A todos dispensava o conselho adequado, a receita de ervas ou a providência de ordem religiosa que o caso impunha. Em cada núcleo de povoação, tinha amigas íntimas entre as mulheres de sua geração interessadas no sobrenatural, e cercava-a o respeito geral.

As personalidades dos dois "búieis" que se submeteram ao teste de Rorschach diferem, tanto do comum dos caraíbas negros, como, sobretuco, entre si. A que se devem essas diferenças? As circunstâncias da educação, os acidentes da biografia, os fatôres caracterológicos podem ser invocados para explicação. Sem querer invalidá-los, chama-se aqui a atenção para uma causalidade de outra or $2 m$. Os agentes do sobrenaturál operam nessa área das condutas coletivas definida como foco cultural; as regras que obrigam o comum dos mortais emanam de sua interpretação, de sorte que, em última análise, êles se regem a si próprios. E' natural, 
pois, que tenham maior latitude de ação. Enquanto em outras sociedades os sacerdotes devem obediência mais estrita aos preceitos religiosos, o "búiei" caraíba negro, que conta com a proteção dos espíritos, se sente bastante forte para quebrá-los. De um dêles, que se tornou bastante conhecido do autor, mas se recusou a submeter-se ao Rorschach, dizia-se a bôca pequena que vivia incestuosamente com a filha, o que constituiria um caso extremo.

Além dessa permissibilidade que decorre da estrutura, há a considerar que os papéis que competem aos "búieis" comportam funçōes diversificadas. Siti Garcia, por exemplo, era chamado a prestar serviços quando outros recursos haviam falhado, e se tornava difícil averiguar a vontade dos "gubida". A boa ordem dos ritos a que presidia era deixada ao encargo das velhas experientes, sendo êle próprio ignorante na matéria. Timotéa Zuñiga, ao contrário, era versada nos menores detalhes dos rituais; além do que, a necessidade de pronunciar diagnósticos, sobretudo em se tratando de moléstias infantis, deve tê-la impelido a dar atenção a indícios tênues. E' lícito supor que o exercício habitual de suas atividades especializadas haja desempenhado parte não pequena no desenvolvimento das personalidades respectivas. O constante comércio com os espíritos certamente favoreceu o desligamento progressivo do quotidiano por parte de Siti, o que não seria possível sem a tendência introversiva que, provàvelmente, manifestou desde cedo. Da mesma forma, a observação meticulosa ter-se-á aguçado pela aplicação metódica a um sem rúmero de casos concretos.

A visão sumária da cultura caraíba negra e a utilização superficial do teste de Rorschach, aqui apresentadas, não permitem conclusões amticiosas, servindo de base apenas a algumas indicações. A influência da psicanálise nos estudos de psicologia, psicologia social e antropologia cultural impôs à consideração geral a importância dos primeiros anos de vida na formação da personalidade. E' desnecessário encarecer que essa descoberta levou a novos rumos na compreensão do homem. Mas os processos dinâmicos de desenvolvimento não cessam passados os cinco anos de idade ou a adolescência, nem se reduzem, daí por diante, à repetição automática das experiências anteriores. Na execução das tarefas que the são adstritas pela ordem social, isto é, por meio do desempenho do papel, o indivíduo forja continuamente a própria conduta. A todo momento, a personalidade é uma organização de componentes vários, cuja natureza e modo de combinar-se cumpre esclarecer. Fixar a priori a proporção dos fatôres é colocar nas premissas o que deve vir como conclusão. Ter-se-á, assim, a demonstração mais ou menos hábil de um ponto de vista, mas não uma pesquisa científica. 


\section{APENDICE I}

Hermenegildo Garcia

Sexo masculino, 42 anos.

I - Hum! - (Toma o cartão e o leva a um altarzinho no fundo da sala, onde o coloca atrás de um castiçal, sôbre a imagem de um santo. Olha-o com grande atenção, e finalmente me pede para deixar todos os cartões com êle, para estudá-los à noite. Consigo convencê-lo de que deve continuar com o teste. Tudo isto leva $5^{\prime}$ e $\left.16^{\prime \prime \prime}\right)$.

1 - Isto é bom. Êste é um mercador. Está olhando para o sol no fundo. Quando entram pela manhã... quando entram com o braço direito em primeiro lugar, é bom sinal. Mas se entram com o braço esquerdo em primeiro lugar, é mau sinal. Esste é bonito.

$$
\text { 5' } 20 \text { "' }
$$

\section{II -1 ' 5"}

1 - Êste também é bom. Êste é de perdição. A raça está aí também. Êste é o fundamento para o trabalho durante o dia. Durante a noite também. E' melhor durante o dia que durante a noite. Uma pessoa recebe muitas ofertas de amizade, mas nã́o há fundamento. O fundo do coração é mau.

$$
\text { 1' } 45 \text { "' }
$$

III - 10"

1 - Êste é a apresentação de uma boa amizade. Êles próprios estão falando: "Não manchemos nossos corações. Sejamos amigos. Eu para você e você para mim". (Repete o mesmo em caraíba). "Como foi ordenado por Nosso Senhor Jesus Cristo".
1 - O que é, Siti? - O espírito da manhã, mas não posso dizer o seu nome. Aqui êle aparece com o braço direito levantado. Aqui, com o esquerdo. - E o que é isto? - A asa.

1 - Sôbre o que você estava falando, Siti? - Yes, sir! Êles estão falando de mãos levantadas, como num juramento, mas é tudo mentira. O fundo é mau. - O que você quer dizer com fundo? - O fundo aqui E' mau. O diamante. As riquezas. - $\mathrm{O}$ que foi aquilo sôbre a raça? (Siti fala em caraíba em voz baixa, como para si mesmo, e depois se cala).

$$
1 \text { - }: \text { - Êles estão falando, }
$$
e seus corações estão unidos, aqui. Esta é a verdadeira lei de Deus. Sem enganos. 
IV - Hum, hum! 45". Êste é bom. do mar.

1 - Uma pele, para o fundo

2 - Vestidos do corpo humano.

3 - Um sinal de morte. Mas tudo é bom, como foi ordenado. Pode-se passar pelo mundo todo sem que êsses façam alguma coisa para a gente.

3' 15 "
1 - ? - Sim, algumas vêzes o fundo do mar, e parece uma bela tapeçaria. (Sorri). Por que não pode ser uma pele?

2 - ? - Êstes aqui. São como meias grandes.

3 - ? - Pode-se chamar de tubarões ou polvos, mas nada mais são que os sinais exteriores da morte. Se é Deus quem os manda, nada se pode fazer, chegou a hora mesmo. Mas se são mandados por um inimigo, uma pessoa pode defender-se, se conhece os meios. Eu estive no mar várias vêzes, e vi muitos tubarões, mas nunca fui atacado por nenhum. - Isto é um tubarão? - Pode ser.

\section{$\mathrm{V}-5^{\prime \prime}$}

1 - As contas do inferno. Êstes todos deviam ser copiados. $\mathrm{Eu}$ gostaria de ficar com êles. Vamos tratar disso depois. O que você estava dizendo, Siti? - Neste mundo somos apenas viajantes. Devemos nos conservar fiéis aos mandamentos de Deus. 1'30" VI - (Olha o verso do cartão)

1 - Com isto, pode-se domar qualquer animal. Pode-se achar um vintém no meio do mato.

Gosto dêstes! Oh, yes! 1'3'
1 - O que você quer dizer com isso, Siti? - O morcêgo é a aparência externa do bruxo, o que tem aliança com o inferno. Pode ter grandes poderes na terra, mas suas contas se acertam no inferno.

1 - ? - E' a pele de um animal. Quando se está tirando a pele, não se deve cortar a cabeça. E' preciso saber preparar, para que tenha virtudes. A gente ye quando vai para o mato, e nenhum animal ataca, e pode-se achar qualquer coisa perdida. 
VII - Hei! 30"

1 - Os santos velhos, caramba! Um está dizendo para o outro: "Não se deve dizer tudo quando há muita gente. Não é a mesma coisa do que quando estamos sós, os dois".

\section{$55^{\prime \prime}$}

\section{VIII - 15"}

1 - A finalidade da árvore. Quando se está abrindo uma roça para plantar, no meio do mato. não se deve destruir as árvores de fruí, ou outras árvores que são ds moradas dos espíritos. As árvores de frutas são para dar comida a êles. Se a gente corta, êles vêm comer o que foi plantado.

1' 10 "'

1 - O sentido universal. Cada povo tem seu sistema. Maus vizinhos.

$$
\text { 1'30" }
$$

\section{IX - Belo! Belo! 25"}

1 - ? - Aqui estão, um em frente do outro. Estão apontando para aquêles que vêm chegando.

1 - ? - Esta é a árvore, e êstes são os animais que estão comendo. Êles podem aparecer sob forma de animais. - Que animais? - Algumas vêzes, animais conhecidos, outras, animais desconhecidos.

1 - ? - Nós somos todos sêres humanos, em todo o mundo. Cada povo tem a sua linguagem, o seu sistema de adorar. Mas isto não é razão para odiarmos uns aos outros. - Sim, mas como é que isto está representado aqui? - Isto parece um mapa-mundi, e êstes dois estão fazendo encantações, um contra o outro.

X — Que beleza! 10"

1 - Isto é o coração do espiritista. Estas são as maracas. A boa vida não é só comer bem e dormir sossegado. E' preciso ter sabedoria também.

Mas as maracas, oh $m y$ ! (Ríse) . 


\section{APENDICE II}

Timotéa Zuñiga

Sexo feminino, 60 anos.

$1-4 ' 30 "$

1 - No centro, parece-me ser um corpo feminino.

2 - Na parte de cima, pareme uma cabeça. Masculina.

3 - De ambos os lados, é como a asa de um pássaro.

1 - Aqui em baixo, a forma de um pé.

4 - Nas duas bordas aqui, parecem-me cabeças de raposa.

5 - No meio aqui, é como a cabeça de um dêsses cachorrinhos peludos.

Não há nada mais neste. 4' 27 '"

II $-35^{\prime \prime}$

1 - Nestes vermelhos, parece-me ver dois pés, direito e esquerdo.

2 - Êstes dois sêres que estão juntos têm o aspecto de homens

3 - E êles se parecem com animais também, de quatro patas. Posso ver duas orelhinhas, cada com a sua orelhinha. Posso ver também um pedaço do rabo cortado.

1 - O que há nesta parte da mancha que faz pensar num corpo feminino? - Esta forma aqui, e isto, que é como uma saia transparente.

2 - Por que masculina? Porque se podem ver os fios da barba.

3 - O que é que fêz pensar nisso? - Esta forma aqui. Por que asa de um pássaro? Por causa das peninhas.

1 - O que é êsse pé? - E' parte do corpo da mulher.

4 - Por que de raposa? Por causa dos focinhos pontudos.

5 - Êste, não estou podendo ver. - E' aqui, na parte mais clara, está vendo agora? - Agora estou vendo. - Pode-se ver o ôlho, aqui, e as orelhas aqui. Os pêlos também? - Sim.

1 - Pés humanos? - Sim, humanos.

2 - Juntos? - Suas mãos estão juntas. - Estão fazendo alguma coisa, como os que estavam falando, ou subindo a montanha? - Não, não podem mover-se, suas mãos estão amarradas.

3 - Que espécie de animais? - (Hesitação). Poderiam ser cachorrinhos, mas eu já disse isso. - Como estão êles? - Estão simplesmente de pé. 
4 - Aqui em baixo, êstes dois pontos têm a forma de duas velas. 4' 20 "'

\section{III $-37^{\prime \prime}$}

1 - Isto me parece ser a forma de um esqueleto.

2 - Há também aqui umas coisinhas do mar, umas conchinhas.

3 - Aqui em baixo, umas coisas como espuma que crescem no mar, e que se podem encontrar nos cayos (ilhotas de pedra).

4 - Virando-se assim, pontas, como as das lanças.

5 - E aqui, é um dedo da mão... como se diz? Ah, sim, polegar .

6 - Ainda virando assim, duas árvores copadas.

7 - Os dois vermelhos agora parecem dois macacos. Têm as mãos amarradas atrás das costas. 5' 7'

IV - 45"

1 - No meio, parece a espinha do corpo humano.

2 - Aqui em baixo, duas coisas como pés de porco.

3 - No outro lado, parece uma nuvem.

4 - Sôbre a nuvem, uma cara de leão .

5 - Uma cabeça com um bico, uma cabeça de águia.
4 - ? - São velas, como as que se acendem para os santos.

1 - Como vê êsse esqueleto? - E' só uma figura. - A figura está se movendo? - Não.

2 - ? - Parecem bichinhos de concha, mas que não se comem.

3 - ? - Êstes aqui. Não é verdadeiramente espuma. São plantas ou animais do mar, que parecem espuma.

4 - Aqui? - Sim, são como as cabeças dos arpões de pesca. E, ao lado dêles - 5 - êstes outros. - Que outros? - Os polegares.

6 - Alguma espécie particular de árvore? - Não, qualquer árvore grande.

7 - Alguma coisa mais sôbre os macacos? - Não. Têm o rabo comprido.

1 - ? - Como nas pinturas dos livros de escola.

2 - ? - E' a forma que êles têm.

3 - O que fêz pensar numa nuvem? - A forma que tem. Só isso? - Sim.

4 - Onde está o resto do leão? - E' só a cabeça .

5 - E' só a cabeça também? - Sim, só a cabeça. 
6 - No outro lado, é como a figura de um homem no alto de uma montanha. Dois homens, e estão fazendo gestos, como se estivessem falando um com o outro.

7 - Aqui, no outro lado, há um homem que está descendo a montanha montado num animal alto, um camelo.

8 - Virando-se assim, uma cabeça de boi com os chifres.

9 - E uma águia com as asas abertas.

$$
\text { 6' } 35 \text { " }
$$

$\mathrm{V}-25^{\prime \prime}$ cego .

1 - Isto me parece um mor-

2 - Garras de... como se diz? ursos.

3 - Na parte de cima, é como um braço humano. do morcego.

1 - Aqui em baixo, os pés

4 - Do outro lado, uma perna humana, mas feminina.

5 - Aqui é como o tubo de uma... como se chama?... uma dessas coisas pretas que aparecem no mar, que chupam a água para cima... - Manga de água? Sim, manga de água. 4' 10 "'
6 - ? - Êste é um homem, e êste o outro. Há outros homens que estão vindo atrás dêste. Êle está carregando um objeto nas mãos para entregar ao outro .

7 - ? - Aqui está o homem, e aqui está a cabeça do camelo, e isto é a montanha. - Por que camelo? - Por causa da forma da cabeça .

$8-?-$ Sim, tudo isto aqui.

9 - Onde está a águia? Aqui. - Não, quero saber onde ela é vista. - Empoleirada no alto de um rochedo.

1 - Como vê o morcego? Está voando. - O que deu a idéia de morcego? - A forma da cabeça aqui, e as orelhas.

2 - ? - E' esta forma aqui.

3 - ? - E' como a parte do braço humano que se curva.

4 - Por que feminina? Porque é mais arredondada, como na mulher.

5 - E' a forma que tem, e por ser preta assim. 


\section{VI} $42 "$

1 - No meio, dois rins, e entre êles a espinha.

2 - Um pouco mais abaixo, a medula espinal.

3 - Aqui em cima, a cabeça de um gato com os seus bigodes.

4 - Uma coisa que é como as asas de um passarinho.

5 - No meio das asas, um pé, de uma senhorita, porque é pequeno.

6 - No meio, é como um corpo humano envergando uma vestimenta aberta, como se fôsse uma alva.

7 - Dos dois lados, a forma de um tronco.

8 - Virando-se assim, o pé de um homem com todos os seus dedos.

9 - Dos dois lados a forma de duas cabeças de cachorros.

10 - Na parte de cima, duas cabeças de senhoras, como se estivessem conversando. A cabeça com todo o cabelo.

11 - Aqui em cima, as cabeças de dois animais, mas não posso saber a que classe pertencem. Mas são pássaros.
1 - ? - E' a mesma coisa do que o outro. Todos êstes se parecem.

2 - ? - Esta parte aqui. - O que faz pensar na medula espinal? - E' por ser branca.

3 - Só a cabeça? - Sim, só a cabeça.

4 - Por que de um passarinho? - Porque são pequenas. - O que é que deu a idéia? Isto aqui, que parece pena.

5 - ? - Sim, olhe um pouco, até se podem ver os dedos.

6 - ? - Aqui está o homem, e esta é a roupa dêle. Onde está a cabeça? - Não se vê a cabeça. E' só o tronco. - O que deu idéia da alva? - Isto aqui, me parece linho ou renda.

7 - ? Um tronco de árvores. Uma árvore cortada.

8 - ? - Sim, neste podemse ver bem os dedos.

a cabeça.

9 - ? - Aqui e aqui. E' só

10 - Por que cabeças de mulheres? - Por causa do cabelo. - Por que parecem estar conversando? - Porque estão gesticulando com as mãos.

$$
11 \text { - Estes aqui? - Sim. - }
$$
Só a cabeça? - Sim. 
VII $-23 ”$

1 - No meio, parece haver uma vela.

2 - No meio, a figura de uma senhora de luto.

3 - Aqui em baixo, uma bandeira. Azul e branca, azul dos lados e branca no meio.

4 - Parece-me ver aqui duas cabeças de meninas, uma do lado direito, outra do lado esquerdo. res.

5 - Isto parece-me ser tôr-

6 - Isto parece-me ser o esqueleto de algum animal. 5' 20 "'

\section{VIII - 10"}

1 - Êstes me parecem ser dois ratos, um do lado esquerdo e outro do lado direito.

2 - Estas me parecem ser duas Virgens, uma do lado direito e outra do lado esquerdo.
1 - Como é esta vela? E' clara, e está desprendendo fumaça. - Onde está a fumaça? - Aqui .

2 - Por que pareceu-lhe uma senhora? - Pela forma do corpo. E ela está usando um vestido justo. - Onde está a cabeça? - Está coberta por um véu. - Por um véu? - As viúvas sempre usam um véu negro como êsse.

3 - Como se podem ver as côres? - As côres a gente tem que imaginar. Assim que é a bandeira de Guatemala ou Costa Rica .

aqui 4 - cabelo. Aqui está a cara e

5 - Como vê as tôrres? Como as casas de uma cidade, que se vêem de longe, quando se vem chegando pela estrada.

6 - ? - Daqui até aqui. De que animal? - Não posso distinguir. - $\mathrm{O}$ que lhe deu a idéia do esqueleto? - A forma.

1 - Os ratos são êstes? Sim. - Como os vê? - Estão cruzando daqui para aqui, estão caçando, talvez. - O que deu a idéia de ratos? - A forma.

2 - Como vê essas Virgens? - E tôrno delas, há uma moldura de madeira, como se fôsse um -icho. - Como estão vestidas? - Como se vestem as Virgens. 
3 - Aqui, parecem ser uns reixinhos.

4 - Esta coisa aqui, parece ser uma cesta cheia de alguma coisa. Tem uma alça aqui e duas dos lados. Há muito mais coisas que cu vejo, mas é preciso tempo para distinguir claramente. Não é que eu não possa explicar. — Não se preocupe em dizer muitas coisas, tudo está indo muito bem. 4' 50 "'

IX - 32” janelas .

1 - Aqui, parece-me haver

2 - E' como as traves no centro de uma casa.

3 - E uma montanha com uma porta.

4 - Como três homens sustentando-se mùtuamente; estão subindo uma montanha, e cada qual se agarra ao vizinho.

5 - Do outro lado, dois homens e uma mulher, quero dizer, uma senhora. Isto é uma cabeça de senhora.

6 - No meio dos dois vermelhos, uma vela acesa.

7 - E duas pernas com os pés.
3 - Como vê êsses peixinhos? - São simplesmente peixinhos . - Estão no mar? - Não, é só a forma.

4 - ? - Isto aqui. - Isto também faz parte? - Sim. - O que é? - Juncos de côr mais clara. - O que faz pensar numa cesta? - A forma. dos navios.

1 - ? - Janelas como as

2 - ? - E' como o ângulo formado pelas traves no meio do telhado da casa.

3 - ? - Esta é a montanha e esta é a porta. - Porta? - E' um buraco por onde se entra. Uma caverna? - Sim, isso mesmo .

4 - ? - Aqui estão êles, cada um dependurado no outro, subindo esta montanha alta.

5 - ? - Aqui está um homem, aqui está o outro, e aqui está a senhora. - Por que uma senhora? - Por causa do cabelo. - Os outros estão subindo uma montanha, e êstes? — Êstes estão aí parados.

6 - Por que acesa? - Podese ver a chama aqui.

7 - Pernas humanas? - Sim. 
lo listado.

8 - Para cima, um triângu-

9 - Aqui, parece haver o olhinho de um dêsses animais pequenos... Como é o nome? Cobaias.

$$
\text { 6' } 55^{\prime \prime}
$$

$\mathrm{X}-47^{\prime}$

1 - Aqui, entre êstes dois objetos, a cabeça de um esquilo. As orelhas estão levantadas.

2 - Para cima, dois animais, duas vacas lutando.

3 - Aqui em baixo, duas coisas como frutinhas, como é que se chamam?... são frutinhas...

4 - E um objeto com a forma de uma cruz, à direita .

5 - Do lado esquerdo, nesta borda, a forma de um candelabro.

6 - Aqui, dois animais, como leões, se jogando um contra o outro .

7 - Aqui em cima, dois homens montados em cavalos.
8 - Não posso achar, talvez não fôsse neste. Ah, sim! Agora estou vendo. - Como é êsse triângulo? - E' o desenho de um triângulo com listas de côr clara.

9 - Aqui está. - Só o olho? - Só o olho.

2 - O que fêz pensar em vacas? - E' porque estão se empurrando com os chifres como as vacas quando brigam.

3 - ? - São frutinhas avermelhadas que nascem na ponta de uma vara fina e comprida.

4 - ? - Sim, uma cruz, como a dos túmulos. - De pedra? - Sim. - Poderia ser de madeira também? - Sim.

5 - ? - Sim, um candelabro, como se vê nas igrejas .

6 - ? - Não estão ainda correndo, estão se preparando para pular um sôbre o outro.

7 - ? - Um está aqui, e o outro, no outro azul. Pode-se ver as patas de trás dos cavalos muito bem, e as costas do homem, mas isso é mais vago. Talvez êles estejam entrando numa parte mais escura da estrada. 
8 - No meio de uns galhos, uma cabeça de homem com uma coroa, como nos nossos autos.

9 - Aqui em baixo, cabecinhas com asas, como cabeças de anjos.

10 - E rabinhos de animais, como rabinhos de ratos.

11 - E balóes, no ar. 7' 30 '"
8 - ? - Como nos nossos autos e nas nossas comédias. Há sempre um rei com uma coroa.

9 - ? - Como nos quadros das igrejas. Há sempre um santo, ou uma Virgem, com êsses anjinhos, só cabeça e asas, voando em tôrno.

$$
10 \text { - ? - Aqui estão. }
$$

11 - Que espécie de balões? - Como os que as crianças fazem para a noite de São João. Balóes de papel.

\section{NOTAS}

1) Melville J. Herskovits, Man and His Works, New York, 1948, pgs. 542, 544.

2) Bruno Klopfer e outros, Developments in the Rorschach Technique, London. Toronto, Wellington, Sydney, s. d., pgs. 307-308. 